\title{
Interactions of Cellular Proteins with the Positive Strand of 3'-Untranslated Region RNA and the Nucleoprotein Gene of Porcine Reproductive and Respiratory Syndrome Virus
}

\author{
FAHAD MAJHAD I AND SANJAY KAPIL \\ Department of Diagnostic Medicine-Pathobiology, College of Veterinary Medicine, Kansas \\ State University, Manhattan, KS 66506
}

\section{INTRODUCTION}

Porcine reproductive and respiratory syndrome virus (PRRSV) is a member of the Arteriviridae family, which includes enveloped and positivesense single-stranded RNA viruses (Meulenberg et al., 1993). The size of the viral genome is approximately $15 \mathrm{~kb}$, and eight functional genes have been identified, five of which encode viral structural proteins (Meulenberg et al., 1997). The organization, structure, and replication strategies of the viral genome are similar to those of coronaviruses (Snijder and Spaan, 1995). Interaction of the $\mathrm{N}$ protein with the 3 '-end of the viral genome suggests that the $\mathrm{N}$ protein may regulate viral RNA synthesis. Several cellular proteins have been reported to bind to the 3'-untranslated region (UTR) of RNA viruses (Nakhasi et al., 1991; Pardigon and Strauss, 1992).

The first step in arteriviral RNA replication is the synthesis of negativestrand RNA from the viral genome. Negative-strand RNA then serves as template for the synthesis of positive-strand RNA and transcription of subgenomic mRNAs (de Vries et al., 1997; Snijder and Meulenberg, 1998).

The Nidoviruses (Coronaviruses and Arteriviruses).

Edited by Ehud Lavi et al., Kluwer Academic/Plenum Publishers, 2001. 
Previous studies with positive-stranded RNA viruses have suggested that viral RNA synthesis is mediated by multiple RNA regions. The 3'-end of viral RNA has the sequence necessary for initiation of the (-) strand RNA synthesis (Lin and Lai, 1993; Lin et al., 1994). Cellular proteins have been shown to regulate replication of the viral genome of several RNA viruses by binding to the 3'(+) UTR of the viral RNA (Lahser et al., 1993; O'Neill and Palese, 1994; Sriskanda et al., 1996). These findings present strong evidence that interactions between these cellular proteins and specific viral RNA regions are necessary for viral RNA synthesis.

In this study, by performing Northwestern blot assay with cytoplasmic extracts of MARC-145 cells, we detected multiple cellular proteins that bind to the 3'UTR/N of PRRSV RNA genome.

\section{MATERIALS AND METHODS}

Extracts from MARC-145, Baby Hamster Kidney (BHK-21), and porcine alveolar macrophage (PAM) cell monolayers were prepared as previously described (Zhang and Lai, 1995). The viral RNA of PRRSV was reverse transcribed with reverse transcriptase (RT), then the cDNA was amplified by the polymerase chain reaction (PCR) with genomic sense primer for 3' UTR/N and anti-genomic sense primer. The PCR product was directly ligated into the $\mathrm{pCR}^{\mathrm{TM} I I}$ plasmid cloning vector (Invitrogen, Carlsbad, CA). In vitro synthesis of RNA transcripts and unlabeled RNA competitors were carried out according to the manufacturer's procedure (Promega, Madison, WI). The ${ }^{32} \mathrm{P}$-labeled RNAs and unlabeled RNA competitors were extracted with phenol-chloroform, precipitated with ethanol, then dissolved in TE buffer $(10 \mathrm{mM}$ Tris- $\mathrm{HCl}[\mathrm{pH} 8.0] ; 1 \mathrm{mM}$ EDTA). Protein extracts $(10 \mu \mathrm{g})$ from MARC-145 cells were separated by electrophoresis in 10\% SDS-PAGE. Electrophoresis was carried out at $200 \mathrm{~V}$ for $45 \mathrm{~min}$, then the protein bands were transferred electrophoretically onto a polyvinylidene difluoride membrane (Gelman Sciences, Ann Arbor, MI). The membrane blots were washed for $30 \mathrm{~min}$ at room temperature with SBB probe buffer $(0.1 \mathrm{M}$ of NaCl; $10 \mathrm{mM}$ Tris [pH 7]; $1 \mathrm{mM}$ EDTA; $0.02 \% \mathrm{BSA} ; 0.02 \%$ Ficoll; $0.02 \%$ polyvinyl pyrrolidone). The blot was incubated in a solution containing SBB buffer with $10 \mu \mathrm{g} / \mathrm{ml}$ of t-RNA and $100 \mu \mathrm{g} / \mathrm{ml}$ denatured salmon sperm DNA (SS DNA) to block nonspecific binding. The ${ }^{32} \mathrm{P}$-labeled RNA probe $\left(8 \times 10^{4} \mathrm{cpm} / \mathrm{ng}\right)$ was added to the SBB buffer and incubated for 1 $\mathrm{h}$ at room temperature. For the competition Northwestern assay, a 1-fold, 10fold and 100-fold excess of unlabeled specific competitor RNAs and nonspecific tRNA and ssDNA were added to the reaction mixture prior to addition of ${ }^{32} \mathrm{P}$-labeled RNA probe. 


\section{RESULTS}

\subsection{Detection of cellular proteins that bind to the 3'UTR/N of the PRRSV positive-strand RNA}

RNA overlay protein blot analysis (ROPBA) was used to determine if protein from MARC-145, PAM, or BHK-21 extracts bound to the 3'-end of the PRRSV positive-strand RNA. The (+)-sense RNA probe used in this experiment was 319 nt long and had the 3'UTR/N of the PRRSV positivestrand RNA. Bands of approximately 53, 50, 46, 37, 33, 28, 26, 2321 and 18 $\mathrm{kDa}$ were detected (Fig. 1).

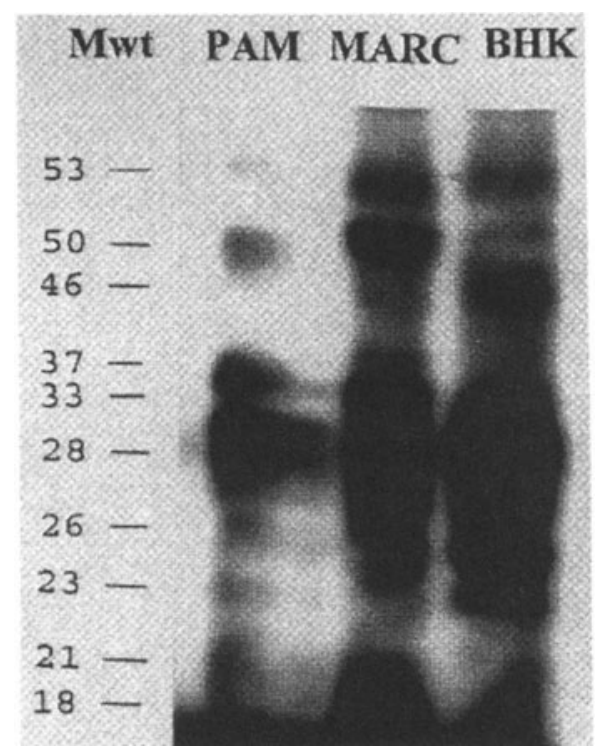

Figure 1. Detection and comparison of the interactions between PRRSV 3'UTR/N RNA and cytoplasmic protein extracts of PAM, MARC-145 and BHK-21 cells by Northwestern blot assay. Cytoplasmic proteins $(10 \mu \mathrm{g} / \mathrm{sample})$ were probed with ${ }^{32} \mathrm{P}$-labeled RNA $\left(8 \times 10^{4} \mathrm{cpm} / \mathrm{ng}\right)$ and incubated with the blot.

To determine whether the protein binding was specific in the Northwestern assay, increasing amounts (1-, 10-, and 100-fold) of unlabeled competitor RNA, non-specific tRNA and ssDNA were preincubated with the cytoplasmic proteins (Figs. 2 and 3; Lanes 1-6). The results indicated an inhibition of protein binding of unlabeled specific homologus competitor RNA, suggesting that the binding is specific (Fig. 2 and 3; Lanes 1-3) but is not affected by heterologus nonspecific competitor RNA (Figs. 2 and 3; Lanes 4-6). 


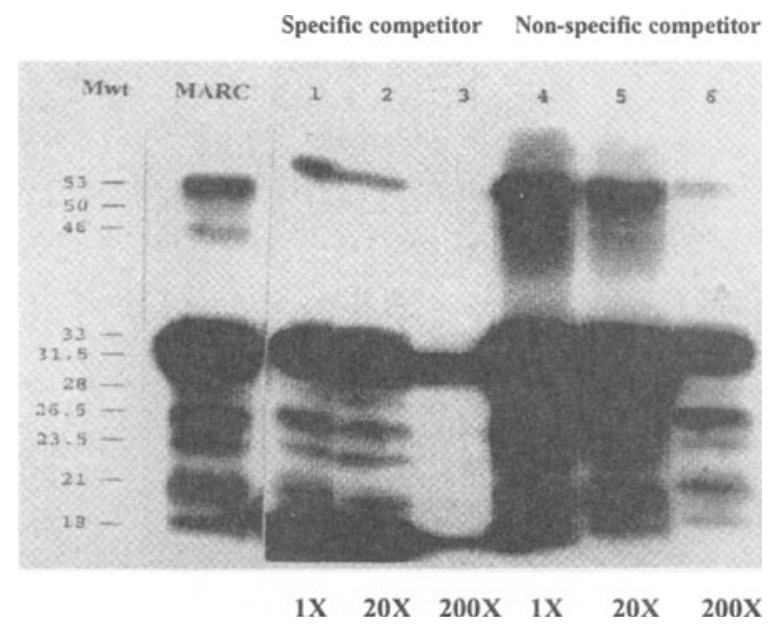

Figure 2. Northwestern blot and competition assay of cytoplasmic extract of MARC-145 cells with PRRSV 3'UTR/N RNA. Cytoplasmic proteins (10 $\mu \mathrm{g} / \mathrm{sample})$ were probed with ${ }^{32} \mathrm{P}$ labeled RNA $\left(1 \times 10^{6} \mathrm{cpm} / 200 \mathrm{ng}\right)$ and incubated with the blot after addition of unlabeled competitors. Lane MARC: cytoplasmic extract no competitor was added. Lanes 1-3: increased amounts of specific unlabeled competitor RNA [ $200 \mathrm{ng}, 2 \mu \mathrm{g}$ and $20 \mu \mathrm{g}$, respectively]. Lanes 4-6: increased amounts of non-specific competitor ssDNA and tRNA [400 ng, $4 \mu \mathrm{g}$ and 40 $\mu \mathrm{g}$, respectively]. The approximate molecular mass $(\mathrm{kDa})$ of each protein is indicated on the left.

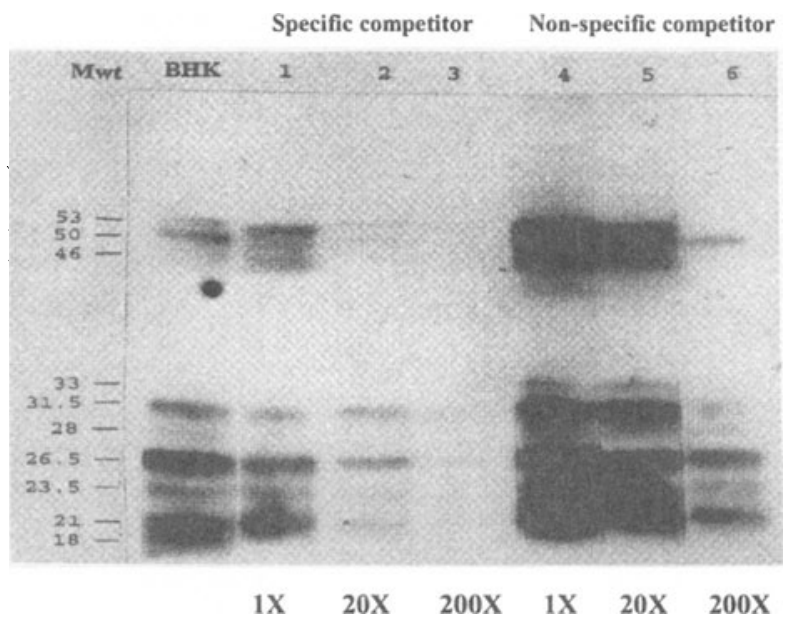

Figure 3. Northwestern blot and competition assay of cytoplasmic extract of BHK-21 cells with PRRSV 3'UTR/N RNA. Cytoplasmic proteins $(10 \mu \mathrm{g} / \mathrm{sample})$ were probed with ${ }^{32} \mathrm{P}$-labeled RNA $\left(1 \times 10^{6} \mathrm{cpm} / 200 \mathrm{ng}\right)$ and incubated with the blot after addition of unlabeled competitors. Lane BHK-21: cytoplasmic extract with no competitor added. Lanes 1-3: increasing amounts of specific unlabeled competitor RNA [200 ng, $2 \mu \mathrm{g}$ and $20 \mu \mathrm{g}$, respectively]. Lanes 4-6: increasing amounts of nonspecific competitor ssDNA and tRNA [400 ng, $4 \mu \mathrm{g}$ and $40 \mu \mathrm{g}$, respectively]. The approximate molecular mass $(\mathrm{kDa})$ of each protein is indicated on the left. 


\section{DISCUSSION}

Very little is known about the nature and the mechanism of PRRSV genome synthesis, arteriviruses may replicate their own RNA through a complex process in which both viral and cellular proteins participate. Involvement of cellular proteins in RNA replication has been demonstrated previously in several RNA viruses including $\mathrm{Q} \beta$ phage, Sindbis virus, brome mosaic virus, influenza virus, cucumber mosaic virus, poliovirus, and potato virus X (Hwang and Brinton, 1998). Cellular proteins have been shown to interact specifically to the $3^{\prime}(+)$ UTR of viral RNA and regulate viral genome replication $5,11,15$. The poly-A tail in arteriviruses is not well studied and its role in PRRSV replication has not yet been delineated. However, the 3'UTR of mouse hepatitis virus (MHV) RNA has been reported to bind a $57 \mathrm{kDa}$ cellular protein which has been identified as the polypyrimidine-tractbinding protein (PTB) (Huang and Lai, 1999).

In this study, using the Northwestern assay, we investigated the interactions of cytoplasmic proteins from PRRSV susceptible PAM cells and MARC-145 cells, and of unsusceptible BHK-21 cell with the 3' UTR/N RNA of PRRSV. We found similar binding patterns among permissive and non-permissive cell lines, suggesting that the differences between these cells might be at the level of cell receptor (Kreutz, 1998). Ten proteins of similar molecular masses were detected in both permissive MARC-145 cells and non-permissive BHK-21 cells (Figs. 2 and 3). Our results are in agreement with a previous finding (Kreutz, 1998) where it was shown that infectious PRRSV was recovered from PRRSV RNA transfected BHK-21 cells thus, the cellular protein may play a role in viral replication. Northwestern technique was used to study the interaction of cellular proteins with the positive strand of $3^{\prime}-\mathrm{UTR}$ and $3^{\prime}-\mathrm{UTR} / \mathrm{N}$ gene of PRRSV. All proteins bound to the 3'UTR of the PRRSV but not to the nucleoprotein sequences. The bands are consistent when both 3'UTR and 3'UTR/N probes were used (data not shown). We were able to identify similar bands $(53,50,46,37,33$, $31,28,26,23,21$ and $18 \mathrm{kDa}$ ) with both probes suggesting the importance of the 3'UTR for interaction with cellular proteins (Figs. 1-3). Also, we studied the effect that salts $\left(\mathrm{NaCl}, \mathrm{KCl}, \mathrm{ZnCl}_{2}\right.$, and $\mathrm{MnCl}_{2}$ at $50 \mathrm{mM}$, $100 \mathrm{mM}, 150 \mathrm{mM}$ and $200 \mathrm{mM}$ ) have on RNA binding of MARC and BHK cytoplasmic protein extracts using Northwestern assay. We found that increasing concentrations of $\mathrm{NaCl}$ reduced the proteins' RNA binding affinities whereas increasing concentrations of $\mathrm{KCl}$ had no effect on binding (data not shown). At this point, it is unclear as to how tightly these proteins must bind to the RNA, which could affect the interaction (binding) stability. We strongly believe that at least one of these proteins may serve as a target for virus replication playing an important role in viral pathogenicity. PETA- 
3/ CD151 a transmembrane protein with $23 \mathrm{kDa}$, that interacts with MARC145 cellular protein, was cloned and identified (Shanmukhappa, K. and S. Kapil, unpublished data). It specifically bound to 3'UTR/N in Northwestern assay. This protein was detected in our investigation, suggesting the importance that may play in viral replication.

\section{REFERENCES}

de Vries, A. A. F., M. C. Horzinek, P. J. M. Rottier, and R. J. de Groot. 1997. The genome organization of the Nidovirales: similartities and differences between arteri-, toro-, and coronaviruses. Semin. Virol. 8: 33-47.

Hwang, Y. K., and M. A. Brinton. 1998. A 68-Nucleotide sequence within the 3' noncoding region of simian hemorrhagic fever virus negative-strand RNA binds to four MA104 cell proteins. J. Virol. 72: 4341-4351.

Huang, P. and M. M. C. Lai. 1999. The complementary strand of the mouse hepatitis virus $3^{\prime}$ 'untranslated region binds polypyrimidine-tract-binding protein. ASV $18^{\text {th }}$ annual meeting W21-9 page 96 (University of Massachusetts, Amherst, Massachusetts, July 1014, 1999).

Kreutz, L. C. 1998. Cellular membrane factors are the major determinants of porcine reproductive and respiratory syndrome virus tropism. Virus. Res. 53:121-128.

Lahser, F. C., L. E. Marsh, and T. C. Hall. 1993. Contributions of the brome mosaic virus RNA-3 3'-nontranslated region to replication and translation. J. Virol. 67:3295-3303.

Lin, Y. J., and M. M. C. Lai. 1993. Deletion mapping of a mouse hepatitis virus defective interfering RNA reveals the requirement of an internal and discontiguous sequence for replication. J. Virol. 67:6110-6118.

Lin, Y. J., C. L. Liao, and M. M. C. Lai. 1994. Identification of the cis-acting signal for minus-strand RNA synthesis of a murine coronavirus: implication for the role of minusstrand RNA in RNA replication and transcription. J. Virol. 68:8131-8140.

Meulenberg, J. J. M., E. J. de Mejjer, and R. J. M. Moormann. 1993. Subgenomic RNAs of Lelystad virus contain a conserved leader-body junction sequence. J. Gen. Virol. 74:1697-1701.

Meulenberg, J. J. M., A. P. van Nieuwstadt, A. van Essen-Zanbergen, and J. P. $\quad$ Langeveld. 1997. Posttranslational processing and identification of a neutralization domain of the GP4 protein encoded by ORF4 of Lelystad virus. J. Virol. 71:6061-6067.

Nakhasi, H., X. Q. Cao, T. A. Rouault, and T. Y. Liu. 1991. Specific binding of host cell proteins to the 3'-terminal stem-loop structure of rubella virus negative-strand RNA. J.Virol. 65:5961-5967.

O'Neill, R., and P. Palese. 1994. Cis-acting signals and trans-acting factors involved in influenza virus RNA synthesis. Infect. Agents. Dis. 3:77-84.

Pardigon, N., and J. H. Strauss. 1992. Cellular proteins bind to the 3' end of Sindbis virus minus strand RNA. J. Virol. 66:1007-1015.

Snijder, E. J., and W. J. M. Spaan. 1995. The coronaviruslike superfamily. In The coronaviridae, p. 239-255. S. G. Siddell (ed.). Plenum Press. New York, NY.

Snijder, E. J., and J. J. M. Meulenberg. 1998. The molecular biology of arteriviruses. J. Gen. Virol. 79:961-979. 
Sriskanda, V. S., G. Pruss, X. Ge, and V.B. Vance. 1996. An eight-nucleotide sequence in the potato virus $\mathrm{X} 3$ ' untranslated region is required for both host protein binding and viral multiplication. J. Virol. 70:5266-5271.

Zhang, X., and M. C. Lai. 1995. Interactions between the cytoplasmic proteins and the intergenic(promoter) sequence of mouse hepatitis virus RNA: correlation with the amounts of subgenomic mRNA transcribed. J. Virol. 69:1637-1644. 